\title{
ANALISIS TATA LETAK FASILITAS PRODUKSI PADA PROSES PRODUKSI MIE TELOR UD SUMBER REZEKI DI KOTA MAKASSAR
}

\author{
Asdi $^{* 1}$, Irwan Abdullah ${ }^{2}$, Pahira $^{3}$ \\ Prodi Manajemen FEB Unismuh Makassar \\ E-mail: ${ }^{* 1}$ asdi@unismuh.ac.id, ${ }^{2}$ Irwan Abdullah@unismuh.ac.id, \\ 3 pahira.febis@gmail.com
}

\begin{abstract}
Abstrak
Penelitian ini bertujuan untuk mengetahui tata letak fasilitas produksi pada proses produksi mie telor Usaha Dagang (UD) Sumber Rezeki di Kota Makassar. Jenis penelitian yang digunakan dalam penelitian ini adalah deskriptif kualitatif.yaitu suatu penelitian yang dimaksudkan untuk mengumpulkan data dan informasi tentang suatu gejala dan fakta terhadap obyek dan tempat penelitian sesuai dengan apa adanya pada saat penelitian berlangsung.

Penelitian dilaksanakan pada pabrik mie telor Usaha Dagang (UD) Sumber Rezeki di Kota Makassar dengan memilih 3 informan yang dianggap representatif mewakili karyawan yang terdiri dari 1 orang sebagai pemilik usaha sekaligus sebagai manajer produksi yang dijadikan sebagai informan kunci, dan 2 orang karyawan bagian teknisi pada bagian proses produksi yang dijadikan sebagai informan non kunci. Teknik pengumpulan data yang digunakan pada penelitian ini adalah teknik wawancara mendalam, observasi dan dokumentasi.

Tata letak fasilitas produksi yang digunakan pada pabrik tersebut adalah tata letak garis yaitu fasilitas yang digunakan saling berkaitan satu sama lain dari satu tahap ke tahap berikutnya sampai dengan tahap akhir. Hasil penelitian menunjukkan bahwa dengan menggunakan tata letak (layout) garis pada proses produksi mampu memperlancar proses produksi sehingga dapat menjamin kualitas dan efektifitas proses produksi.
\end{abstract}

Kata Kunci : Tata Letak Fasilitas Produksi

\section{PENDAHULUAN}

Perancangan tataletak fasilitas yang baik pada suatu perusahaan akan mempengaruhi kelancaran operasi dan aktivitas-aktivitas yang terjadi di dalam perusahaan. Selain itu juga dapat lebih mengoptimalkan ruang yang terdapat pada suatu perusahaan tersebut. Tata letak fasilitas produksi mempunyai dampak terhadap proses operasi perusahaan bila ditinjau dari segi kegiatan proses produksi, dimana terjadinya perpindahan material dari satu unit ke unit lainnya sehingga tata letak fasilitas pada proses produksi sangat diperlukan untuk dapat menunjang aspek kelancaran proses produksi. Oleh karena itu perlu adanya suatu pertimbangan dalam membuat atau mendesain tata letak fasilitas produksi yang lebih efektif dan efisien untuk menghasilkan proses produksi yang lancar, efektif dan efisien sertta kualitas hasil produksi yang terjamin.

\section{A. Tata Letak}

Menurut Apple dalam (Iveline Anne Marie, 2015:60) tata letak adalah suatu rancangan fasilitas, membentuk konsep, dan mewujudkan sistem pembuatan barang atau jasa.

$$
\text { Sedangkan menurut (Hani }
$$
Handoko, 2016;105) Tata letak atau layout harus dirancang untuk memungkinkan perpindahan yang ekonomis dari orangorang dan bahan-bahan dalam berbagai proses dan operasi perusahaan.

Penentuan layout peralatan dan proses produk meliputi pengaturan letak fasilitas-fasilitas operasi termasuk 
mesin-mesin, personalia, bahan-bahan, perlengkapan untuk operasi, penanganan bahan (material handling), dan semua peralatan serta fasilitas untuk terlaksananya proses produksi dengan lancar dan efisien. Penentuan letak fasilitas-fasilitas produksi dalam pabrik erat huubungannya dalam pendirian bangunan pabrik (building).

Menurut (Hani Handoko, 2016;10 7-111) ada 4 pola dasar umum layout diantaranya sebagai berikut:

1. Layout Fungsional

Layout Fungsional merupakan pengelompokan bersama mesin-mesin dan personalia untuk melaksanakan pekerjaan yang serupa atau sejenis.

2. Layout Produk

Layout produk atau sering disebut layout garis, berarti bahwa kebutuhankebutuhan operasi produk mendominasi dan menentukan layout mesin-mesin peralatan-peralatan lainnya.

\section{Layout Kelompok}

Layout Kelompok (group layout) memisah-misahkan daerah-daerah dan kelompok-kelompok mesin bagi pembuatan komponen-komponen yang memerlukan pemrosesan yang sejenis.

\section{Layout Posisi Tetap}

Layout posisi tetap (fixed position layout) sering digunakan untuk produkproduk besar dan kompleks, layout semacam ini adalah pengaturan fasilitas produksi dalam membuat barang dengan letak barang yang tetap atau tidak dipindah-pindah.

\section{B. Tujuan Tata Letak}

Adapun tujuan tata letak atau layo ut Menurut (Hani Handoko, 2016: 106) yaitu peralatan dan proses produksi pada hakekatnya menupakan optimasi pengaturan fasilitas-fasilitas operasi sehingga nilai yang diciptakan oleh sistem produktif maksimum. Secara lebih terperinci, layout fasilitas bertujuan untuk menggunakan ruangan yang tersedia seefektif mungkin, meminimumkan biaya penanganan bahan dan jarak angkut, menciptakan kesinambungan dalam proses produksi, menyederhanakan proses produksi, mendorong semangat dan efektivitas kerja para karyawan dan barang-barang yang sedang diproses, serta menghindari berbagai bentuk pemborosan.

Manfaat tata letak (layout) yaitu sebagai berikut:

1. Meningkatkan jumlah produksi, tata letak fasilitas yang baik akanmemberikan kelancaran proses produksi dan akhimya akan memberikan output yang lebih besar dengan biaya yang sama atau lebih sedikit, jam tenaga kerja dan jam kerja mesin lebih kecil.

2. Mengurangi waktu tunggu, tata letak fasilitas yang baik akan memberikan keseimbangan beban dan waktu antara satu mesin dengan mesin atau departemen dengan departemen yang lain.

3. Manfaat proses pemindahan bahan, pada sebagian besar proses produksi, bahan baku akan lebih sering dipindahkan jika dibandingkan dengan tenaga kerja, mesin maupun peralatan produksi yang lain.

4. Penghematan penggunaan ruangan, terjadinya penumpukan material dalam proses dan jarak antara masingmasing mesin terlalu berlebihan akan menambah luas bangunan yang dibutuhkan.

5. Efisiensi penggunaan fasilitas, suatu tata letak fasilitas yang terencana secara baik, dapat menciptakan pendayagunaan elemen produksi seperti tenaga kerja, mesin maupun peralatan lebih efektif dan efisien.

6. Mempersingkat waktu proses, dengan memperpendek jarak antara satu mesin dengan mesin yang lain atau antara satu operasi denga operasi 
yang lain dan mengurangi penumpukan bahan dalam proses atau mengurangi waktu tunggu.

7. Meningkatkan kepuasan dan keselamatan kerja, pengaturan tata letak fasilitas pabrik secara baik dapat menciptakan suasana ruang dan lingkungan kerja yang nyaman, aman, tertib dan rapi, sehingga kepuasan dan keselamatan kerja akan dapat lebih ditingkatkan.

8. Mengurangi kesimpang-siuran, banyaknya material yang menunggu, gerakan yang tidak perlu, dan banyaknya perpotongan dari aliran proses produksi yang dapat mengakibatkan kemacetan.

\section{Prinsip dasar penyusunan Layout}

Prinsip dasar penyusunan atau perencanaan pengaturan tata letak fasilitas pabrik menurut (Zulian Yamit, 2003:132) adalah sebagai berikut:

1. Integrasi secara total, Prinsip ini menyatakan bahwa tata letak fasilitas pabrik dilakukan secara terintegrasi dari semua faktor yang mempengaruhi proses produksi menjadi satu unit organisasi yang besar.

2. Jarak perpindahan bahan paling minimum, Waktu perpindahan bahan dari satu proses ke proses lainnya dalam suatu industri dapat dihemat dengan cara mengurangi jarak perpindahan tersebut seminimum mungkin.

3. Memperlancar aliran kerja, Sebagai kelengkapan dari prinsip jarak perpindahan bahan seminimum mungkin, prinsip memperlancar aliran kerja diusahakan untuk menghindari adanya gerakan aliran balik (backtracking), gerakan memotong (cross movement), kemacetan (congestion). Dengan kata lain, material diusahakan bergerak terus tanpa adanya interupsi atau gangguan jadwal kerja.

4. Kepuasan dan keselamatan kerja, tata letak yang baik apabila pada akhirnya mampu memberikan keselamatan dan keamanan dari orang yang bekerja di dalamnya.

5. Fleksibilitas, Tata letak atau layout yang baik dapat juga mengantisipasi perubahan-perubahan dalam bidang teknologi, komunikasi maupun kebutuhan konsumen. Fleksibilitas untuk diadakan penyesuaian atau pengaturan kembali (relayout) maupun layout yang baru dapat dibuat dengan cepat dan murah.

\section{Fasilitas Produksi}

Perencanaan fasilitas yang baik dapat berpengaruh terhadap proses produksi yang terjadi dalam pembuatan suatu produk. Fasilitas produksi merupakan sesuatu yang dibangun, diadakan atau diinvestasikan guna melaksanakan aktivitas produksi. Perencanaan tata letak fasilitas produksi berhubungan erat dengan proses perencanaan dan pengaturan letak mesin, peralatan, aliran bahan, dan pekerja pada masing-masing stasiun kerja (work station).

\section{E. Proses Produksi}

Proses adalah cara, metode dan teknik bagaimana sesungguhnya sumbersumber (tenaga kerja, mesin, bahan dan dana) yang ada diubah untuk memperoleh suatu hasil. Sedangkan produksi adalah kegiatan untuk menciptakan atau menambah kegunaan suatu barang atau jasa. Menurut (Rusdi Nur, 2017:27) yang menyatakan bahwa: proses produksi dapat diartikan sebagai cara, metode dan teknik untuk menciptakan atau menambah kegunaan suatu barang atau jasa dengan menggunakan sumber-sumber (tenaga kerja mesin, bahan-bahan dan dana) yang ada. Ada 4 fungsi terpenting dalam proses produksi antara lain: 
1. Proses pengolahan, merupakan metode atau teknik yang digunakan untuk pengolahan masukan (input).

2. Jasa-jasa penunjang, saran yang berupa pengorganisasian yang perlu untuk penetapan teknik dan metode yang akan dijalankan, sehingga proses pengolahan dapat dilaksanakan secara efektif dan efisien.

3. Perencanaan, merupakan penetapan keterkaitan dan pengorganisasian dari kegiatan produksi dan operasi yang akan dilakukan dalam suatu dasar waktu atau priode tertentu.

4. Pengendalian atau pengawasan, merupakan fungsi untuk menjamin terlaksananya kegiatan sesuai dengan yang direncanakan, sehingga maksud dan tujuan untuk penggunaan dan pengolahan masukan input) pada kenyataannya dapat dilaksanakan.

\section{F. Jenis-jenis ProsesProduksi}

MenurutManahan

P.

Tampubolon(2014:123) di dalam system operasional dikenal ada 4 jenis proses produksi yaitu:

1. Proses produksi terputus-putus (Intermittent process), Proses produksi terputus-putus merupakan kegiatan operasional yang mempergunakan peralatan produksi yang disusun dan diatur sedemikian rupa, yang dapat dimanfaatkan untuk secara fleksibel (multipurpose)untuk menghasikan berbagai produk atau jasa.

2. Proses produksi terus-menerus (Continous Process)Proses produksi terus-menerus merupakan proses produksi yang mempergunakan peralatan produksi yang disusun dan diatur dengan memperhatikan susunan urutan-unutan atau routing dalam menghasikan produk atau jasa, serta arus bahan didalam proses telah terstandarisir.

3. Proses produksi berulang-ulang (Repetitive process), Proses produksi berulang-ulang merupakan proses produksi yang menggabungkan fungsi intermittent process dan continuous process.

4. Proses produksi masa (Mass Customization), Proses produksi campuran merupakan proses produksi dengan menggabungkan; Intermittent Process, Continuous process, serta repetitive process yang menggunakan berbagai komponen bahan, mempergunanakan teknik skedul produksi dan mengutamakan kecepatan pelayanan.

\section{METODOLOGI PENELITIAN Jenis Penelitian}

Jenis penelitian yang digunakan yaitu deskriptif kualitatif. Penelitian kualitatif menggambarkan suatu makna yang bertujuan untuk menemukan jawaban terhadap suatu fenomena melalui prosedur yang sistematis dengan menggunakan metode kualitatif.

\section{Fokus Penelitian}

Pada penelitian ini fokus penelitiannya mengenai bagaimana tata letak fasilitas produksi dalam proses produksi mie telor pada pabrikmie telor UD Sumber Rezeki di Kota Makassar.

\section{Lokasi dan Waktu Penelitian}

Penelitian ini dilakukan pada pabrik UD Sumber Rezeki di jalan Sultan Alauddin Lorong 8 Nomor 2Kota Makassar, yang berlangsungselama 2 bulan yakni pada bulan Mei dan Juni 2019.

\section{Sumber Data}

1. Data Primer, yaitu data yang diperoleh dari karyawanpabrik mie UD Sumber Rezeki Kota Makassar yang dipilih sebagai informan penelitian.

2. Data Skunder, adalah data yang diperolehberupa dokumentasi dari kantor UD Sumber Rezeki di Kota 
Makassar yang ada kaitannya dengan fokus penelitian.

3. InformanPenelitian

Dalam penelitian ini terdapat 2 jenis informanyaitu :

a. Informan kunci, yaitu karyawan pada tingkat kepala bagian operasional yang mengetahui dan memahami fokus penelitian yang sedang diteliti yaitu tentang tata letak fasilitas produksi pada proses produksi mie telor.

b. Informan non-kunci, yaitu karyawan atau pekerja yang langsung menagani teknik operasional produksi sehingga bersentuhan langsung dengan tata letak fasilitas produksi sehingga dianggap mengetahui dan memahami permasalahan dan fokus penelitian yang sedang diteliti.

\section{Pengumpulan Data}

Dalam penelitian ini metode pengumpulan data sebagai berikut:

\section{Pengamatan (observation)}

Yaitu melakukan pengamatan langsung terhadap objek dan fokus penelitian yaitu tata letak mesin dan fasiliktas produksi pada UD Sumber Rezeki.

2. Wawancara Mendalam

Pengumpulan data dengan cara wawancara mendalam dilakukan untuk mengetahui informasi dari narasumber. cara pengumpulan data yang di peroleh dari wawancara yaitu melalui pemilik Pabrik Mie telor UD Sumber Rezeki di Kota Makassar, berupa wawancara secara langsung yang berkaitan dengan variabel penelitian yaitu Tata letak fasilitas produksi.

3. Dokumentasi

Pengumpulan data dengan dokumentasi dilakukan melalui pengambilan datadata yang berkaitan dengan penelitian dari tempat penelitian yaitu pada Pabrik Mie UD Sumber Rezeki di Kota Makassar.

\section{Instrumen Penelitian}

Instrumen yang juga dapat diartikan sebagai "alat bantu" memiliki peran yang sangat berpengaruh terhadap penelitian. Oleh sebab itu, instrumen penelitian sangat dibutuhkan agar penelitian dapat berjalan secara efisien dan mudah. Instrumen penelitian paling utama dalam penelitian ini adalah peneliti. Jadi, dalam hal ini peneliti adalah instrumen kunci dari penelitian itu sendiri.

\section{Teknik Analisis Data}

Teknik analisis data yaitu teknik yang digunakan peneliti untuk menjawab permasalahan yang ada dalam perusahaan. Dengan menggunakan teknik analisis data kualitatif yang berupa dokumentasi, wawancara dan observasi. Aktivitas dalam analisis data dilakukan dengan tiga tahap yaitu reduksi data, penyajian data dan penarikan kesimpulan.

1. Reduksi data

Reduksi Data ialah teknik menganalisis data dengan cara merangkum, memilih pokok dan memfokuskan pada hal-hal yang penting.

2. Penyajian Data

Penyajian data merupakan sekumpulan informasi tersusun yang memberi kemungkinan untuk menarik kesimpulan dan pengambilan tindakan selanjutnya. Bentuk penyajian data antara lain berupa teks naratif, matrik, grafik, maupun bagan.

3. Penarikan Kesimpulan

Semua data yang telah direduksi, digambarkan lagi secara rinci agar mudah dipahami oleh peneliti maupun orang lain. Data yang dirincikan ini adalah data yang telah diperoleh dari hasil pengumpulan data, baik berupa observasi maupun wawancara.

\section{HASIL DAN PEMBAHASAN}


Berdasarkan hasil wawancara yang dilakukan kepada pemilik pabrik Sumber Rezeki dan beberapa pekerja pada bagian produksi maupun pemasaran yang terdapat di pabrik Mie Usaha Dagang (UD) Sumber Rezeki Kota Makassar maka berikut ini adalah deskripsi atau uraian hasil analisis maupun interpretasi data dalam pemilihan tata letak fasilitas produksi dan deskripsi tentang proses produksi pada produk Mie Usaha Dagang (UD) Sumber Rezeki Kota Makassar adalah sebagai berikut:

\section{Tata letak fasilitas produksi}

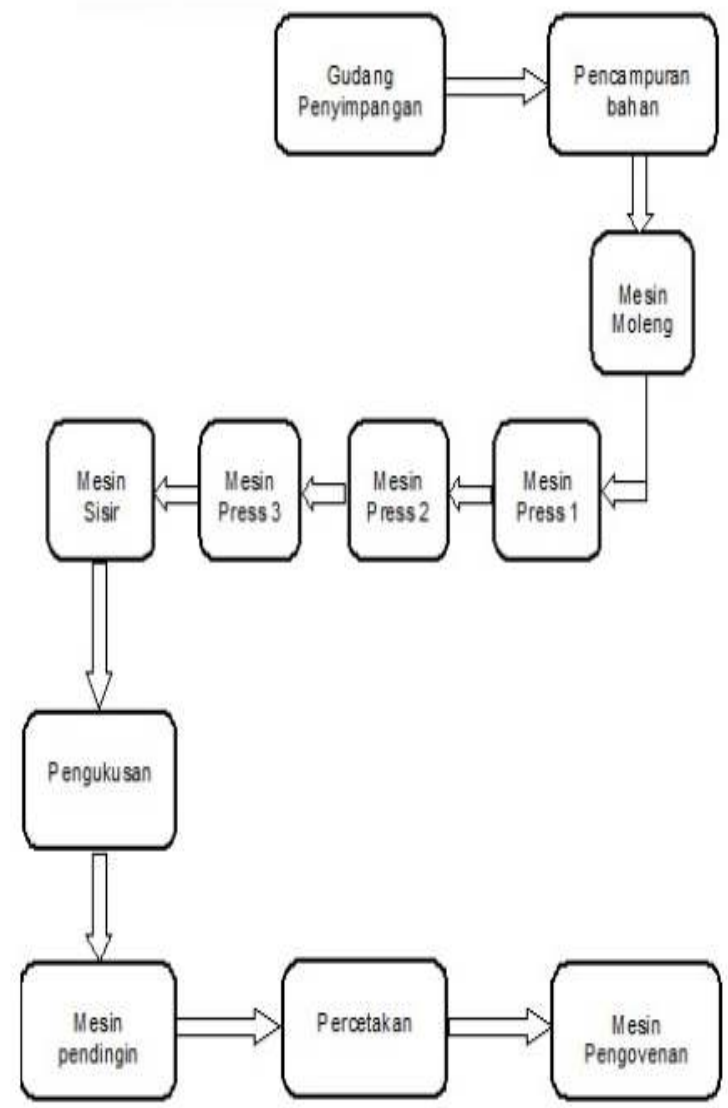

Tata letak fasilitas produksi yang digunakan pada proses produksi yaitu tata letak produk atau yang lebih dikenalnya yaitu tata letak garis. Dalam penerapan tata letak fasilitas produksi yang digunakan pada pabrik tersebut membuat pekerja lebih bebas bergerak karena pabrik tersebut bisa dikatakan sempit. Selain itu dengan tata letak produk atau tata letak garis yang digunakan pekerjaan lebih terarah sehingga proses produksi lebih lancar dan waktu proses juga lebih cepat.

\section{Mesin yang digunakan}

Industri manufaktur khususnya pada perusahaan maupun pabrik makanan memiliki jenis mesin yang berbeda-beda. Mesin yang terdapat pada pabrik mie Usaha Dagang (UD) Sumber Rezeki memiliki enam jenis mesin dengan fungsi yang berbeda-beda.

a. Mesin Pencampuran

Mesin pencampuran diletakkan pada bagian sudut pabrik karena tempat tersebut sangat tepat untuk berdampingan dengan gudang penyimpangan bahan baku sehingga memudahkan karyawan dalam melakukan proses produksi. Mesin pencampuran bahan ini berfungsi untuk mencampur bahan-bahan yang digunakan pada proses produksi mie.

b. Mesin Moleng

Mesin moleng ini diletakkan di samping kanan mesin pencampuran karena untuk memudahkan karyawan mengangkat adonan yang telah tercampur. Mesin memiliki fungsi untuk menyatukan kembali bahan-bahan yang telah tercampur agar adonan menjadi lebih bagus.

c. Mesin Press 1,2,3 dan Mesin sisir Mesin press1 memiliki fungsi untuk membuat lembaran-lembaran adonan menjadi tipis, mesin 2 berfungsi untuk membuat lembaran-lembaran adonan lebih tipis dari lembaran adonan yang dihasilkan pada mesin press 1 kemudian mesin press 3 membuat lembaran lebih tipis lagi dibandingkan dengan mesin press 1 dan mesin press 2, dan yang terakhir yaitu mesin sisir, mesin sisir memiliki fungsi untuk membuat produk menjadi mie setelah melalui beberapa tahapan dari mesin-mesin sebelumnya. 
d. Langsang dan Pengukusan

Penempatan fasilitas produksi yang bernama langsang umumnya tidak menentu karena jenis fasilitas ini mudah dan ringan untuk dipindahkanpindahkan. Langsang berfungsi pada bagian pengukusan.

e. Pengovenan

Pengovenan di letakkan pada bagian sudut dan agak jauh dari proses karena pada bagian letak pengovenan tersebut sangat panas sehingga pengovenan memiliki ruang khusus dalam mengoven mie.

\section{Letak Mesin Sesuai Fungsinya}

Pabrik UD Sumber Rezeki menggunakan tata letak mesin sesuai dengan urutan produksinya. Mulai dari mesin pencampuran, moleng, press 1, press 2, press 3, sisir. Dalam pabrik pemeliharaan mesin-mesin sangat diperlukan untuk menghasilkan kualitas produk sehingga Usaha Dagang (UD) sumber Rezeki memiliki jadwal dalam pembersihan mesin-mesin yaitu dilakukan 3 kali seminggu. Mesin dan peralatan yang dipergunakan dalam proses produksi dan operasi harus terjamin tetap tersedia untuk dapat digunakan, sehingga dibutuhkan adanya kegiatan pemeliharaan atau perawatan.

\section{Penerapan tata letak garis}

Pabrik mie Usaha Dagang (UD) Sumber Rezeki telah menerapkan tata letak garis yang memiliki banyak keunggulan dalam proses produksinya yaitu dapat memudahkan karyawan, proses produksi lebih ter arah serta dapat memperlancar proses produksi. Pada penerapan tata letak garis yang digunakan dapat menghemat ruangan yang sempit karena fasilitas-fasilitas hanya berjajar dan berjalan sesuai dengan fungsinya masing-masing. Dengan penerapan tata letak garis yang telah digunakan pada pabrik mie UD Sumber Rezeki juga memiliki kendala yang terdapat pada mesin yaitu kerusakan yang terjadi pada salah satu menyebabkan proses produksi terhambat.

\section{Proses Produksi}

Proses produksi yang diterapkan pada pabrik Usaha Dagang (UD) Sumber Rezeki adalah proses produksi secara terus menerus karena pada pabrik ini hanya memproduksi satu macam produk sehingga proses produksi secara terus-meneruslah yang lebih tepat untuk digunakan. Dalam proses produksi yang perlu diperhatikan adalah keselamatan kerja para pekerja yang harus diperhatikan karena tidak berjalan proses produksi apabila pekerja terluka, selain itu pembersihan mesin-mesin semua misalnya dinamo yang terdapat pada mesin serta bahan-bahan yang sudah mengering harus dibersihkan.

Hasil penelitian menunjukkan bahwa pabrik mie Usaha Dagang (UD) Sumber Rezeki telah menggunakan tata letak yang hampir sama dengan tata letak sebelumnya namun pada fasilitas produksi yang digunakan itu jauh berbeda dengan yang sebelumnya.Tata letak fasilitas produksi yang digunakan sebelumnya sudah efektif namun kurangnya fasilitas serta penataan tata letak yang membuat pekerjaan terhambat karena sempitnya akan ruangan produksi. Oleh karena itu, pemilik pabrik maupun bagian teknisi menggunakan Layoutatau tata letak garisdan membuka mesin-mesin yang tidak dibutuhkan lagi sehingga ruangan proses produksi menjadi luas dan fasilitas produksi ditambah untuk memperlancar proses produksi. Dengan peletakan fasilitas dengan menggunakan tata letak garis yang digunakan dapat mengefesienkan waktu dalam proses produksi serta tidak terjadi pemborosan dalam penyiapan bahan-bahan produksi, keunggulan dari tata letak garis tersebut adalah mudah dalam pengaturan fasilitas produksi yang terletak di dalam 
pabrik UD Sumber Rezeki di Kota Makassar.

Hal demikian mendukung pendapat dari (Hani Handoko, 2016:106) yang menyatakan bahwa peralatan dan proses produksi pada hakekatnya merupakan optimasi pengaturan fasilitas-fasilitas operasi sehingga nilai yang diciptakan oleh sistem produktif maksimum. Selain itu perlu pula dipenuhi kebutuhan para karyawan dalam menjalankan proses produksi. Secara lebih terperinci, tata letak fasilitas bertujuan untuk menggunakan ruangan yang tersedia seefektif mungkin, meminimumkan biaya penanganan bahan dan jarak angkut, menciptakan kesinambungan dalam proses produksi, menyederhanakan proses produksi, mendorong semangat dan efektivitas kerja para karyawan dan barang-barang yang sedang diproses, serta menghindari berbagai bentuk pemborosan.

\section{KESIMPULAN}

Berdasarkan pendeskripsian pada hasil penelitian dan pembahasan yang tercantum pada bab sebelumnya, maka peneliti dapat menarik kesimpulan sebagai berikut:

1. Tata letak fasilitas produksi yang digunakan pada UD Sumber Rezeki di Kota Makassar sudah efektif karena mudah dalam pengaturan fasilitas produksi yang terletak di dalam pabrik mie tersebut.

2. Tata letak fasilitas menjadikan pekerjaan lebih terarah dan tidak berantakan. Di samping itu aspek pengawasannya yang relatif mudah serta dapat mengefesienkan waktu dalam proses produksi sehingga tidak terjadi pemborosan waktu dalam pembuatan mie.

3. Tata letak fasilitas yang digunakan pada UD Sumber Rezeki Kota Makassar adalah tata letak garis sehingga dapat menjadikan proses produksi lebih cepat serta dalam memproduksi bahan mulai dari bahan baku sampai menjadi bahan jadi menjadi lebih terarah.

\section{SARAN}

Seorang peneliti harus mampu meberikan sesuatu yang berguna bagi perkembangan ilmu pengetahuan, instansi atau lembaga serta berbagai pihak yang berkaitan dengan penelitian yang dilakukan mengenai tata letak fasilitas produksi pada proses produksi mie telor UD Sumber Rezeki Kota Makassar. Adapun saran dari peneliti adalah sebagai berikut:

1. UD Sumber Rezeki sebaiknya menyediakan mesin-mesin yangmodern serta dapat menambah karyawan karena mengingat banyaknya peminat mie serta jumlah permintaan pesanan mie meningkat.

2. UD Sumber Rezeki mengembangkan manajemen pemasaran tentang promosi untuk mendapatkan pelanggan yang dapat mempercayai kualitas produk mie demi persaingan pada pabrik-pabrik mie lainnya.

3. Dalam penelitian ini variabel yang dianalisis adalah tata letak fasilitas produksi pada proses produksi maka dari itu sebaiknya untuk peneliti selanjutnya dapat meneliti tentang tata letak gudang agar tidak hanya letak fasilitas produksi yang diperhatikan akan tetapi tata letak gudang maupun tata letak fasilitas dapat diperbaiki sehingga proses produksi menjadi lebih efektif.

\section{DAFTAR PUSTAKA}

Marie, I.A., dan Chaiyadi, T.N., 2015. Perancangan Tata Letak Pabrik Dan Analisis Ekonomi Pada Pt Xyz Extension. Jurnal Ilmiah Teknik Industri. Vol. 3 No 1. 
Handoko, H.T. 2016. Dasar- Dasar Manajemen Produksi dan Operasi. Jilid I. BPFE Yogyakarta: Yogyakarta.

Yamit, Zulian. 2003. Manajemen Produksi dan Operasi. Edisi II. Ekonisia: Yogyakarta.

Nur, Rusdi dan Suyuti, M.A. 2017. Pengantar Sistem Manufaktur. Yogyakarta: CV. Budi Utama.
Tampubolon, P. Manahan. 2014. Manajemen Operasi \& Rantai Pemasok (Operation and Supply-chain Management) Edisi Pertama. Jakarta: Mitra Wacana Media.

Pangestu Subagyo, 2000, Manajemen Operasi, Edisi Pertama, BPFE Yogyakarta: Yogyakarta. 